\title{
PERBANDINGAN PEMBERIAN MINYAK KUNING TELUR AYAM DAN BIOPLACENTON TERHADAP GAMBARAN HISTOLOGI KULIT
}

\author{
Rondius Solfaine $^{1}$, Dian Ayu Kartika Sari ${ }^{1}$, Yoko Shagitha ${ }^{1}$, Ratna Widyawati ${ }^{\text {* }}$ \\ ${ }^{1}$ Fakultas Kedokteran Hewan, Universitas Wijaya Kusuma Surabaya \\ *Email: drhratnagrey@gmail.com
}

\begin{abstract}
This study was conducted to determine the comparison of re-epithelialization, granulation and the number of inflammatory cells infiltration between topical application of chicken yolk oil and bioplacenton on white rat (Rattus norvegicus) skin that has induced with second degree burn wound. This research was a laboratory experimental study using 18 male white rats divided into control positive $(\mathrm{K}+)$ group, bioplacenton $(\mathrm{Pl})$ and chicken yolk oil (P2). Observation of the re-epithelialization, granulation and inflammatory cells infiltration were carried out 14 days after the rat were induced with second degree burn wound. The necropcy was performed on the $14^{\text {th }}$ day and then the skin organs were treated with HE staining and observed under a microscope. Data analysis was performed using Kruskal-Wallis followed by Mann Whitney. The results of the analysis showed that $K+$ had significantly different results $(P<0.05)$ compared to $P 1$ and $P 2$ in the scores of reepithelialization, granulation and the number of inflammatory cell infiltrations. $P 1$ and $P 2$ were not significantly different $(P>0.05)$. In this study, it can be concluded that chicken egg yolk has a comparable effect with bioplacenton toward the score of re-epithelialization, granulation and the number of inflammatory cell infiltration.
\end{abstract}

Keywords: Chicken yolk oil, Bioplacenton, Re-epithelialization, Granulation, Inflammatory cell infiltrations

\section{PENDAHULUAN}

Luka bakar merupakan keluhan dermatologik yang terjadi ketika beberapa atau seluruh lapisan kulit dihancurkan oleh cairan panas, kontak dengan benda panas atau nyala api. Luka bakar juga dapat disebabkan akibat radiasi ultraviolet, radioaktivitas, listrik atau bahan kima, serta kerusakan pernafasan akibat menghirup asap. (Sandhiutami, dkk., 2018). Luka bakar merupakan salah satu dari bentuk perlukaan paling merusak diantara bentuk perlukaan yang lain, karena memiliki efek besar terhadap kondisi fisik, psikis dan fisiologi pasien.
Luka bakar masih merupakan salah satu penyebab kematian dan disabilitas tertinggi di dunia. (Lee, et al., 2014). Terdapat pembagian derajat luka bakar yaitu luka bakar derajat I (luka bakar superfisial), luka bakar derajat II (luka bakar dermis) dan luka bakar derajat III (luka bakar menyeluruh). Luka bakar derajat II merupakan luka bakar dengan trauma mencapai lapisan dermis tetapi dengan masih ada elemen epitel yang tersisa seperti sel epitel basal, kelenjar sebasea, kelenjar keringat dan folikel rambut (Setiawan, dkk., 2015). 
Obat yang sering digunakan untuk pengobatan luka bakar adalah gel Bioplacenton. Bioplacenton memiliki sediaan berupa gel dengan kandungan aktif ekstrak placenta $10 \%$ dan Neomycin sulfate $0,5 \%$. Gel Bioplacenton diindikasikan untuk mengobati luka bakar, luka dengan infeksi, luka kronik dan jenis luka yang lain (KalbeMed, 2020).

Pengobatan luka bakar harus dilakukan secara rutin untuk mendapatkan kesembuhan optimal. Kesulitan mendapat obat di tempat terpencil dan penggunaan obat dalam jumlah banyak yang tidak murah dapat menjadi kendala dalam pengobatan luka bakar, sehingga dibutuhkan produk alternatif menggunakan bahan yang mudah didapat, dapat digunakan dalam jumlah banyak dan ekonomis.

Minyak kuning telur merupakan obat alternatif multifungsi dengan indikasi spesifik pada dematologi dan demam. Minyak kuning telur ayam juga digunakan sebagai pengobatan tambahan untuk penyakit jantung. Minyak kuning telur ayam populer di Jepang, Korea dan Bangsa China (China daratan, Taiwan, Hong Kong, Malaysia, dll) (Hu, et al., 2012).

Minyak kuning telur ayam merupakan sumber kaya fosfolipid, trigliserida, kolesterol, tokoferol dan karotenoid yang memiliki manfaat untuk penyembuhan luka, antiinflamasi, anti penuaan, antimikrobial dan anti rakhitis. Minyak kuning telur ayam juga dilaporkan memiliki sifat analgesik sehingga direkomendasikan untuk kasus inflamasi persendian. Minyak kuning telur ayam tidak mengandung protein sehingga aman untuk pasien penderita alergi produk telur (Madan and Sanju, 2016).

Berdasarkan uraian diatas, maka peneliti tertarik untuk mengetahui perbandingan pengaruh pemberian topikal minyak kuning telur ayam dan gel Bioplacenton terhadap gambaran histologi kulit pada tikus putih yang diinduksi luka bakar derajat II.

\section{MATERI DAN METODE}

Penelitian ini merupakan penelitian eksperimental laboratorik untuk mengetahui perbandingan pemberian topikal minyak kuning telur ayam (Gallus gallus) dan bioplacenton terhadap reepitelisasi, granulasi dan infiltrasi sel radang luka bakar pada tikus putih (Rattus norvegicus) yang diinduksi luka bakar derajat II.

Variabel bebas pada penelitian ini adalah sediaan topikal minyak kuning telur ayam (Gallus gallus) dan gel bioplacenton yang diberikan untuk perawatan luka bakar derajat II pada kulit tikus putih (Rattus norvegicus). Variabel terikat adalah re-epitelisasi, granulasi dan infiltrasi sel radang pada luka bakar derajat II pada kulit tikus putih (Rattus norvegicus) dan variabel kendali adalah 18 ekor tikus putih jantan (Rattus norvegicus).

Sampel tikus putih jantan yang akan digunakan berjumlah 18 ekor tikus yang dibagi menjadi 3 kelompok yang terdiri dari: (1) kelompok kontrol positif $(\mathrm{K}+)$ yang hanya diberi luka bakar tanpa pengobatan, (2) kelompok perlakuan 1 (P1) yang diberi perlakuan pemberian gel Bioplacenton, dan (3) kelompok perlakuan 2 (P2) yang diberi perlakuan pemberian topikal minyak kuning telur ayam.

Jumlah sampel yang dibutuhkan dihitung berdasarkan rumus yang dikemukakan oleh Arifin and Wan (2017) dengan jumlah sampel minimum 10/k + 1 Sehingga didapatkan jumlah sampel minimum 18 ekor. 
Analisis data dilakukan dengan data semi kuantitatif mode skoring.

Sedangkan untuk membedakan perlakuan dengan kontrol dilakukan analisis non-parametrik menggunkan aplikasi SPSS dengan metode KruskalWallis, apabila terdapat perbedaan nyata maka akan dilajutkan dengan uji Mann Whitney.

Penilaan mikroskopis dilakukan dengan 5 lapang pandang berbeda dengan mengamati re-epitelisasi, granulasi dan infiltrasi sel radang dilakukan sesuai dengan sistem skoring yang dideskripsikan oleh Hazrati, et al. (2010).

\section{A. Lokasi dan Waktu Penelitian}

Penelitian ini dilaksanakan di Laboratorium Hewan Coba Fakultas Kedokteran Universitas Airlangga Surabaya dan pembuatan preparat histopatologi akan dilakukan di Fakultas Kedokteran Universitas Airlangga

\section{B. Prosedur Penelitian}

\section{Pembuatan minyak kuning telur ayam}

Telur ayam direbus hingga matang selama 10-15 menit. Kemudian kuning telur dipisahkan dari putih telur. Kuning telur yang sudah dipisahkan kemudian dihaluskan dan dipanaskan menggunakan wajan diatas api kecil hingga berwarna hitam pekat dan mengeluarkan minyak. Kuning telur yang berwarna hitam pekat kemudian disaring untuk diambil minyaknya.

\section{Pembuatan luka bakar}

Tikus putih dianestesi menggunakan Ket-A-Xyl ${ }^{\circledR}$. Punggung tikus kemudian dicukur seluas $3 \times 3 \mathrm{~cm}$ kemudian dibersihkan menggunakan alkohol. Pembuatan luka bakar derajat II pada punggung tikus dilakukan menggunakan batang alumunium dengan diameter $10 \mathrm{~mm}$ yang dipanaskan hingga $100^{\circ} \mathrm{C}$ menggunakan air mendidih. Batang alumunium kemudian ditempelkan pada
Surabaya. Penelitian kemudian dilanjutkan dengan skoring dan foto histopatologi di Laboratorium Patologi Fakultas Kedokteran Hewan Universitas Wijaya Kusuma Surabaya. Penelitian ini akan dilangsungkan pada bulan Mei 2020.

\section{B.Alat dan Bahan}

Peralatan yang digunakan untuk penelitian ini terdiri dari disposable syringe $1 \mathrm{cc}$ sebagai alat injeksi anastesi, sarung tangan steril, masker, silet untuk mencukur bulu, batang alumunium dengan diameter $10 \mathrm{~mm}$, kompor, panci dan kandang pemeliharaan.

Sedangkan bahan - bahan yang diperlukan dalam penelitian ini adalah alkohol, obat anastesi Ket-A-Xyl ${ }^{\circledR}$, formalin 10\%, alkohol 70\%, alkohol 80\%, alkohol 90\%, alkohol 96\%, alkohol absolut, etanol, xylol, dan pewarna hematoksilin eosin, minyak kuning telur ayam dan gel bioplacenton.

kulit yang sudah dicukur selama 15 detik tanpa disertai penambahan tekanan (Pereira, et al., 2012).

\section{Pengobatan luka bakar}

Tikus putih jantan sebanyak 18 ekor dibagi kedalam 3 kelompok dengan perlakuan diberikan selama 1 kali sehari dengan dosis secukupnya menutupi permukaan luka, selama 14 hari.

\section{Pembuatan preparat histologi}

Area luka bakar dipotong dan difiksasi menggunakan larutan formalin $10 \%$. Kemudian dilanjutkan dengan proses Pewarnaan menggunakan Hematoxylin-Eosin (HE).

\section{Skoring}

Skoring dilakukan menggunakan mikroskop dengan menggunakan metode skoring yang dideskripsikan oleh Hazrati, et al. (2010). 
HASIL

Tabel 1. Uji mann whitney re-epitelisasi

\begin{tabular}{cccc}
\hline Perlakuan & $\begin{array}{c}\text { Mann } \\
\text { Whitney- U }\end{array}$ & $\begin{array}{c}\text { Asymp. } \\
\text { Sig }\end{array}$ \\
\hline K+ & P1 & 3.000 & 0.011 \\
& & & \\
\cline { 2 - 4 } & P2 & 2.000 & 0.007 \\
\hline P1 & P2 & 15.000 & 0.575 \\
\hline
\end{tabular}

Tabel 2. Uji mann whitney granulasi

\begin{tabular}{cccc}
\hline Perlakuan & $\begin{array}{c}\text { Mann } \\
\text { Whitney- U }\end{array}$ & $\begin{array}{c}\text { Asymp. } \\
\text { Sig }\end{array}$ \\
\hline K+ & P1 & 2.000 & 0.007 \\
& & & \\
\cline { 2 - 4 } & P2 & 2.000 & 0.007 \\
\hline P1 & P2 & 18.000 & 1.000 \\
\hline
\end{tabular}

Tabel 3 Uji mann whitney infiltrasi sel radang

\begin{tabular}{cccc}
\hline Perlakuan & $\begin{array}{c}\text { Mann } \\
\text { Whitney- U }\end{array}$ & $\begin{array}{c}\text { Asymp. } \\
\text { Sig }\end{array}$ \\
\hline $\mathrm{K}+$ & $\mathrm{P} 1$ & 1.000 & 0.004 \\
& & & \\
\cline { 2 - 4 } & $\mathrm{P} 2$ & 2.000 & 0.007 \\
\hline $\mathrm{P} 1$ & $\mathrm{P} 2$ & 15.000 & 0.523
\end{tabular}

Berdasarkan hasil analisis, didapatkan masing - masing nilai sig $(\mathrm{P}<$ 0.05) yang menunjukkan adanya perbedaan nyata rata - rata nilai re epitelisasi, granulasi dan jumlah infiltrasi sel radang antar kelompok kontrol positif dengan kelompok perlakuan. Sedangkan kelompok perlakuan 1 (P1) dan kelompok perlakuan 2 (P2) masing - masing menunjukkan nilai sig $(\mathrm{P}>0.05)$ yang menunjukkan tidak adanya perbedaan nyata rata - rata nilai re - epitelisasi, granulasi dan jumlah infiltrasi sel radang. Hal ini menunjukkan bahwa minyak kuning telur (P1) efektif digunakan sebagai pengobatan luka bakar sesuai dengan penelitian Rastegar, et al. (2011). Sedangkan antar kelompok perlakuan P1 dan $\mathrm{P} 2$ tidak ada perbedaan signifikan ( $\mathrm{P}$ $>0.05)$.

\section{Re-epitelisasi}

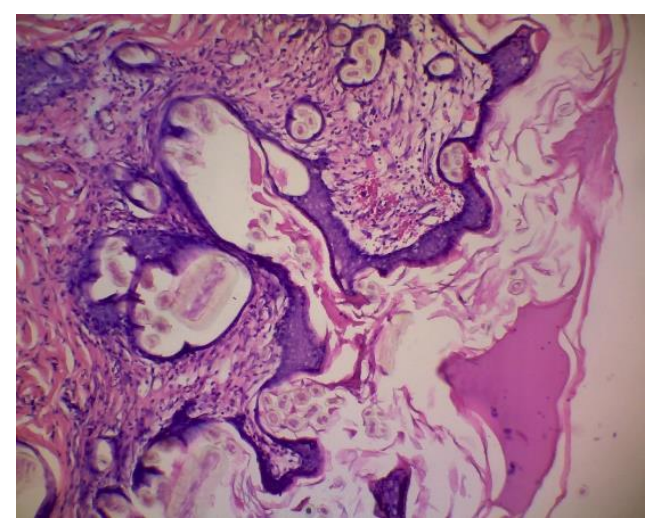

Gambar 1. kulit kelompok kontrol positif $(\mathrm{K}+)(\mathrm{HE}, 10 \mathrm{x})$

Gambaran histopatologi kulit pada kelompok kontrol positif $(\mathrm{K}+)$ menunjukkan adanya re-epitelisasi yang buruk, hemoragi dan keropeng (scab).

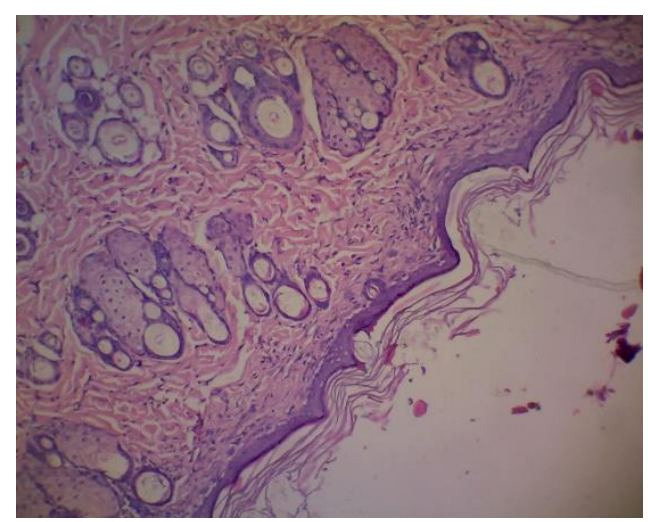

Gambar 2. kulit kelompok P1 (Bioplacenton) (HE, 10x)

Gambaran histopatologi kelompok P1 menunjukkan adanya re-epitelisasi yang baik dengan batas batas yang terlihat jelas. 


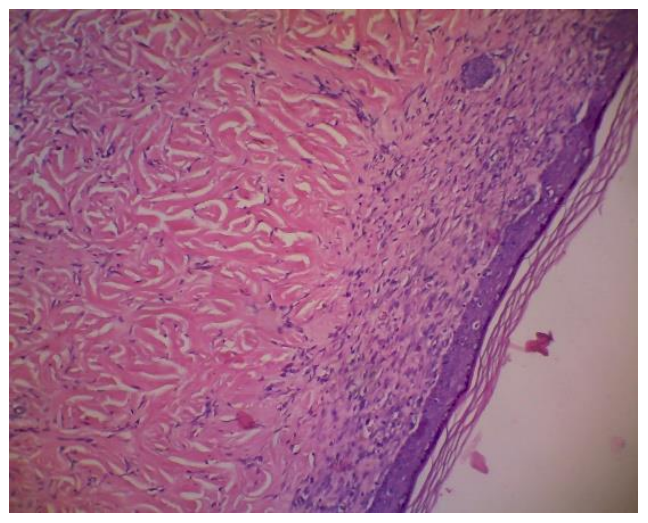

Gambar 3. kulit kelompok P2 (Minyak kuning telur ayam) (HE, 10x)

Gambaran histopatologi kelompok P2 menunjukkan adanya re-epitelisasi yang baik dengan batas batas yang terlihat jelas.

Pada hasil pengamatan gambaran histopatologis luka, kelompok P1 dan P2 ditemukan memiliki proses re-epitelisasi yang lebih baik dari kelompok kontrol positif. Ditandai dengan pembentukan epidermis yang baik mulai dari stratum korneum hingga stratum basalis yang terlihat jelas. Sedangkan pada kelompok kontrol positif, masih ditemukan banyak jaringan $s c a b$ diatas permukaan epidermis dan bagian - bagian epidermis yang inkomplit.

Re-epitelisasi terjadi melalui mekanisme migrasi, proliferasi dan diferensiasi. Minyak kuning telur ayam dapat menstimulasi pelepasan IL-8 dari keratinosit yang berperan untuk memanggil neutrofil, limfosit dan makrofag. Neutrofil, limfosit dan makrofag kemudian distimulasi oleh TNF- $\alpha$ dan IL-1 untuk menghasilkan IL-8 kembali. IL-8 dapat menstimulasi migrasi epitel dan proliferasi sehingga terjadi reepitelisasi dan penutupan luka. (Hahn, et al. 2014)

Pada gel Bioplacenton terdapat kandungan aktif berupa ektrak plasenta. Plasenta merupakan sumber yang kaya akan faktor pertumbuhan (Growth
Factor). Ektrak plasenta memiliki kandungan FGF (Fibroblast Growth Factor) dan TGF (Transforming Growth Factor). FGF dan TGF berperan penting dalam proses re-epitelisasi, TGF-beta dapat meningkatkan proses migrasi keratinosit dan fibroblas yang membantu proses re-epitelisasi. (Chakraborty, et al., 2009).

\section{Granulasi}

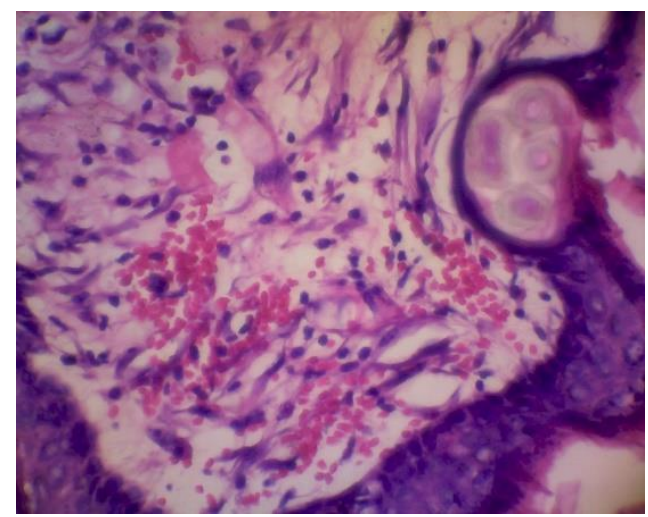

Gambar 4. kulit kelompok kontrol positif $(\mathrm{K}+)(\mathrm{HE}, 40 \mathrm{x})$

Gambaran histopatologi kulit pada kelompok kontrol positif $(\mathrm{K}+)$ menunjukkan adanya granulasi yang tidak padat, banyak infiltrasi sel radang dan hemoragi.

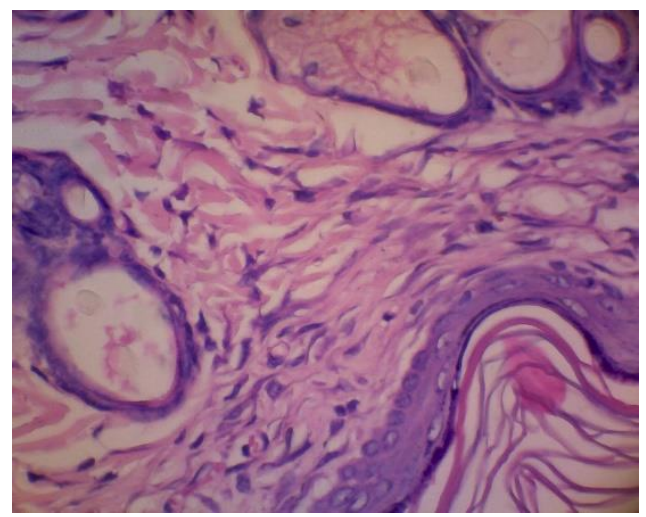

Gambar 5. kulit kelompok P1 (Bioplacenton) (HE, 40x)

Gambaran histopatologi kelompok P1 menunjukkan adanya granulasi yang padat dan rapi, sedikit infiltrasi sel radang dan pembentukan pembuluh darah baru. 


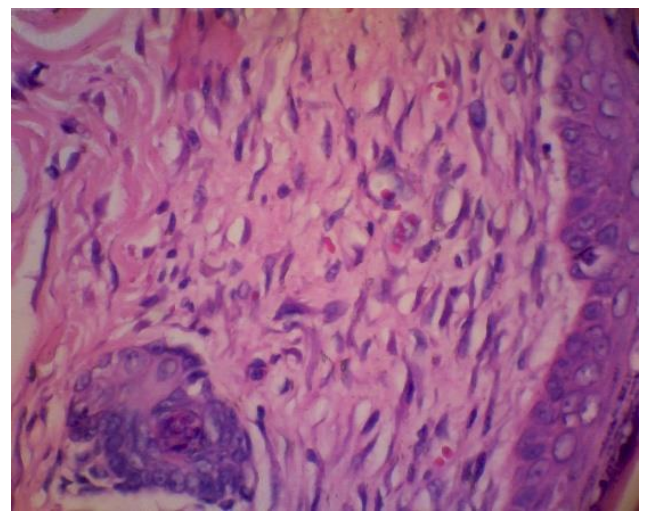

Gambar 6. kulit kelompok P2 (Minyak kuning telur ayam) (HE, 40x)

Gambaran histopatologi kelompok P2 menunjukkan adanya granulasi yang padat dan rapi, sedikit infiltrasi sel radang dan pembentukan pembuluh darah baru.

\section{PEMBAHASAN}

Kelompok P1 dan P2 memiliki proses granulasi yang lebih baik dari kelompok kontrol positif. Hal ini ditandai dengan jaringan granulasi yang lebih padat, pembentukan pembuluh darah baru, fibroblas yang ramping memanjang dan sedikit sel radang. Sedangkan pada kelompok kontrol positif ditemukan jaringan granulasi yang kurang padat dengan hemoragi dan edema, banyak infiltrasi sel radang dan pembentukan fibroblas yang tidak seragam.

Hal tersebut dikarenakan minyak kuning telur ayam merupakan sumber vitamin larut lemak seperti vitamin E, vitamin $\mathrm{D}$ dan vitamin A. Vitamin E yang terkandung dalam minyak kuning telur adalah $\alpha$-tokoferol (Kovalcuks, 2015). Tokoferol dapat mempercepat tingkat kesembuhan luka dan meningkatkan jumlah konten protein secara signifikan, selain itu secara histologis, penggunaan tokoferol dapat meningkatkan pembentukan jaringan epitel dan kolagen yang lebih baik dan rapi (Lin, et al., 2012)

Sedangkan ekstrak plasenta pada gel bioplacenton bekerja dengan cara meningkatkan produksi TGF-beta yang dapat menstimulasi pembentukan jaringan granulasi. Selain itu ekstrak plasenta juga dapat meningkatkan produksi VEGF yang meningkatkan pembentukan pembuluh darah baru (Hong, et al., 2010).

\section{Infiltrasi sel radang}

Jumlah infiltrasi sel radang kelompok P1 dan P2 lebih sedikit dari kelompok kontrol positif. Sel radang yang banyak dijumpai berupa sel radang mononuklear karena kondisi luka sudah memasuki hari ke -14. Hal ini menunjukkan tingkat kesembuhan kelompok P1 dan P2 lebih tinggi dari pada kelompok kontrol positif.

Hal tersebut dikarenakan minyak kuning telur ayam memiliki efek anti inflamasi dan analgesik terutama pada minyak yang diekstraksi menggunakan metode panas. Efek anti inflamasi dari minyak kuning telur didapat dari kandungan Gamma-linolenic acid (GLA) yang merupakan asam lemak omega-6 yang secara natural terdapat pada kuning telur (Mahmoudi, et al., 2013). Linolenic acid atau asam linoleat dapat mempengaruhi status struktural dan imunologis kulit karena dapat mempengaruhi permeabilitas kulit. Asam linoleat dapat menghambat produksi eikosanoid proinflamasi, ROS (Reactive Oxygen Species) dan sitokin, sehingga dapat mempengaruhi respon inflamasi dan kesembuhan luka (Silva, et al., 2018). Hal yang sama dikemukakan oleh Hahn, et al. (2014) yaitu minyak kuning telur dapat mengurangi proses inflamasi dan produksi ROS, sehingga membantu kesembuhan luka terutama pada luka kronis. Produksi interleukin selain IL-8 dalam minyak kuning telur ayam dikurangi sebanyak $70 \%$ sehingga minyak kuning telur ayam berperan dalam mengurangi proses proinflamasi yang ekstensif.

Sedangkan ekstrak plasenta juga memiliki sifat anti-inflamasi dengan cara membatasi dan mengaktivasi mediator inflamasi dan menghambat produksi prostaglandin. Prostaglandin berperan 
dalam membatasi atau mengaktivasi proses agregasi platelet, yang merupakan bagian penting dalam proses inflamasi. Sehingga ekstrak plasenta memiliki sifat anti agregasi platelet. (Chakraborty, et al., 2009).

\section{KESIMPULAN}

Berdasarkan hasil penelitian yang telah dilakukan, maka dapat disimpulkan bahwa minyak kuning telur ayam memiliki efek yang sebanding dengan bioplacenton terhadap proses reepitelisasi, granulasi dan infiltrasi sel radang pada kulit tikus putih dengan luka bakar derajat II.

\section{REFERENSI}

Sandhiutami, Ni Made Dwi, Yesi Desmiaty, Nuryenti, 2018. Efek Pemberian Ekstrak Etanol Daun Jati Belanda (Guazuma ulmifolia Lamk.) Terhadap Penyembuhan Luka Bakar Derajat IIA Pada Tikus Putih. Fakultas Farmasi. Universitas Pancasila.

Lee, K. C., Kavita Joory, Naiem S. Moiemen, 2014. History of burns: The past, present and the future. Burns \& Trauma, October 2014, Vol 2, Issue 4.

Setiawan, M. Riza, Afiana Rohmani, Ika Dyah Kurniati, Kanti Ratnaningrum, Rochman Basuki, 2015. Buku Ajar Ilmu Bedah. Fakultas Kedokteran. Universitas Muhammadiyah Semarang.

KalbeMed, 2020. Bioplacenton $^{\circledR}$. https://kalbemed.com/ProductsDiseases/Products/Read-ProductArticle/ArtMID/458/ArticleID/1 79/BIOPLACENTON. Diakses Mei 2020

Hu, T. M., Tsuo-Hung Lan and El-Wui Loh, 2012. An Emerging Complimentary Medicine-Yolk
Oil Made from Heating Method. Journal of Traditional and Complementary Medicine Vol. 2, No. 2, pp. 202-203.

Madan, K. dan Sanju Nanda, 2016. Hen egg yolk oil: A potential source of bioavailable lutein and zeaxanthin for skin and sun protection. World Journal Pharmaceutical Sciences. 5(1): 71-80.

Guo, S. dan L.A. DiPietro, 2010. Factors Affecting Wound Healing. Center for Wound Healing and Tissue Regeneration, Department of Periodontics, College of Dentistry. University of Illinois at Chicago.

Tiwari, V.K., 2019. Burn wound: How it differs from other wounds?. Department of Burns and Plastic Surgery, VMMC and Safdarjung Hospital, New Delhi, India

Alhasyimi, Ananto A., 2016. INDUKSI RE-EPITELISASI PADA PROSES PENYEMBUHAN LUKA GINGIVA OLEH APLIKASI TOPIKAL EKSTRAK DAUN SAGE (Salvia officinalis L.) KONSENTRASI 50\% (Kajian In Vivo Pada Tikus Sprague Dawley. Bagian Ortodonsi, Fkg Universitas Gadjah Mada, Yogyakarta

Gonzales, Ana C.O., Zilton A.A., Tila F.C. Alena R.A.P.M., 2017. Wound healing-A ltiteratire review. Anais Brasileiros de Dermatologia.

Kartikaningtyas, Aqilla T., Prayitno dan Sri P. L., 2015. Pengaruh Aplikasi Gel Ekstrak Kulit Citrus Sinensis terhadap Epitelisasi pada Penyembuhan Luka Gingiva Tikus Sprague Dawley. Majalah Kedokteran Gigi Indonesia 
Nasution, Abdillah I., 2016. BUKU AJAR BIOMOLEKULER untuk Ilmu Kedokteran Dasar. Syiah Kuala University Press

Batthacharya, Geetika K., 2017. Pathology for Dental Students (Second Edition). ELSEVIER

Serhan, Charles N., Peter A.W., Derek W.G., 2010. Fundamentals of Inflamation. Cambridge University Press

Anderson, James M., 2013. Inflamation, Wound Healing and the ForeignBody Response dalam Biomaterials Science (Third Edition). Elsevier Academic Press

Anderson, James M., 2019. Biocompatibility and Bioresponse to Biomaterials dalam Principles of Regenerative Medicine (Third Edition). Elsevier Academic Press

Ivanalee, S. K., Ira Sari Y., Maya Nurwartanti Y., Nusdianto Triakoso, Iwan Sahrial H., Amung Logam S., 2018. Efektivitas Sugar Dressing (100\% Gula) dalam Meningkatkan Kepadatan Kolagen pada Proses Penyembuhan Luka Bakar Buatan pada Kulit Tikus Putih (Rattus norvegicus) Jantan. Jurnal Medik Veteriner Vol.1 No.3: 134-141

Navadiya, S.K., Yagnesh L. Vaghani, Mukesh P. Patel, 2012., Study of Topical Placental Extract Versus Povidone Iodine and Saline Dressing in Various Diabetic Wounds. National Journal of Medical Research. Volume 2: Issue 4.

Arifin, Wan N. dan Wan Mohd Z., 2017. Sample Size Calculation in Animal Studies Using Resource
Equation Approach. Malaysia Journal Medical Sciences 24(5): 101-105.

Hazrati, M., D. Mehrabani, A. Japoni, H. Montasery, N. Azarpira, A.R. Hamidian-shirazi, N. Tanideh, 2010. Effect of Honey on Healing of Pseudomonas aeruginosa Infected Burn Wounds in Rat. Journal of Applied Animal Research Res. 37 (2010): 161165.

Pereira, D.d.S.T.P., Maria Helena M.L.R, Nicodemos Teles d.P.F, Ana Maria d.A.C.L, Maria Tereza d.S.C, 2012. Development of Animal Model for Studying Deep Second-Degree Thermal Burns. Hindawi Publishing Corporation Journal of Biomedicine and Biotechnology Volume 2012, Article ID 460841.

Rastegar, F., N. Azarpira, M. Amiri, A. Azarpira, 2011. The Effect of Egg Yolk Oil in the Healing of Third Degree Burn Wound in Rats. Iran Red Crescent Medical Journal 13(10):739-743.

Hahn, Jurgen B., August B., Heiker B., Irina E., Stefan K., Maila R., Valentina S., Nadja Z., 2014. CELLULAR RESPONSES TO EGG-OIL (CHARISMONO). ACTA MEDICA (Hradec Králové)

Chakraborty, P.D., De D., Bandyopadhyay S., Bhattacharyya D., 2009. Human aqueous placental extract as a wound healer. Journal of wound care

Kovalcuks, Aleksandrs, 2015. Comparison of Bioactive Compound Content in Egg Yolk Oil Extracted from Eggs Obtained from Different Laying Hen Housing Systems. World 
Academy of Science, Engineering and Technology International Journal of Nutrition and Food Engineering

Lin, Teoh S., Azian A.L., Noor A.A.H., Wan Z.W.N., Musalmah M., 2012. Evaluation of Topical Tocopherol Cream on Cutaneous Wound Healing in Streptozotocin-Induced Diabetic Rats. Hindawi Publishing Corporation
Hong, Jong Won, Won Jai Lee, Seung Boem Hahn, Bom Jin Kim, Dae Hyun Lew, 2010. The Effect of Human Placenta Extract in a Wound Healing Model. Annals of Plastic Surgery, volume 65

Silva, Jessica R., Beatriz B., Carolina M.C.K., Thamiris C., Mariah B.P.A., Hosana G.R., 2018. Wound Healing and Omega-6 Fatty Acids: From Inflamation to Repair. Hindawi Publishing 